\title{
Effect of nutritional supplements on queen cell production in honey bee (Apis mellifera)
}

\author{
Nazia Haleem, Neelima R. Kumar and Rajinder Kaur* \\ Department of Zoology, Panjab University, Chandigarh, 160014 (Punjab), INDIA \\ *Corresponding author. E-mail: raj.pu85@gmail.com \\ Received: November 1, 2014; Revised received: April 18, 2015; Accepted: May 20, 2015
}

\begin{abstract}
Honey bees are an important means of earning a living both at small and commercial levels. Maximum benefits can be obtained from strong colonies and in order to maintain strong colonies a good beekeeper requeens the colonies every second year. This requires a number of queens. The advances in beekeeping technology have made it possible to rear queens artificially or naturally. There is scope for improvement of these methods. The aim of the present study was to investigate if nutritional supplements could facilitate queen cell production in spring and autumn seasons. Becosule, thiamine, yeast and sugar solutions were fed to the honey bee colonies. The greatest number of queen cells was produced in the yeast fed colonies in spring. Bee mortality was observed in case of becosule. Perhaps the formulation contained some components which were toxic to honey bees. The effect on queen cell production by the different nutrients was in the order of Yeast $>$ Thiamine $>$ Becosule.
\end{abstract}

Keywords: Honey bee queen, Nutritional supplements, Protein, Seasons, Yeast

\section{INTRODUCTION}

Beekeeping is the art of maintaining and managing honey bee colonies for the benefit of man. The advantages of the activities of bees and their product are very well known. Previously, most beekeepers kept bees for obtaining honey and bee wax. With the innovations in beekeeping techniques beekeepers have been able to exploit this small scale venture for various other products such as pollen(Kaur et al., 2013a; 2013b; 2013c), propolis (Kalia et al., 2013), bee venom, royal jelly, quality queens and package bees. Various therapeutic potential of honey bee hive products were also reported by many workers. They are commonly used to treat the human ailments from traditional times against respiratory ailments, toothache, burns, chest pain, gastrointestinal disorders, fatigue etc. (Meda et $a l$. , 2004). The idea for packing bees was first conceived by the A. I. Root for sale and transport (Eckert and Shaw, 1960) to orchardists and farmers who use bees for the purpose of pollination and to the beekeepers. Larvae and adults are highly dependent on the food stores in colony and adult honey bees adapt their

foraging according to the need and supply of proteins and carbohydrates (Schmickl and Crailsheim, 2004; Brodschneider and Crailsheim, 2010 ). A package hive contains about 3500-4500 workers with or without queen and is provisioned with sugar syrup. Quality queens can be produced by natural as well as by artificial manipulation for selected characters. Beekeepers desire to have queens that have good characters such as industriousness, prolificness, gentleness, tendency to swarm less, enemy and disease resistance and absence of absconding. Good beekeeping products requires requeening of all the colonies every second year or if possible every year. Queen is also required when she injured or old or dies due to disease, is lost in mating flight or during migration for pollination. Queen rearing therefore becomes necessary for all these replacements as well as improvement of strain and for further propagation of selected stock.

The significance of the study included that Rearing of queens by the beekeeper with desired traits can improve the colony as these traits are passed to her progeny by the queen. The rearing of queen is also important for the replacement of old queen or lost queen by young queen by the beekeepers because young queens are swarm less and more prolific egg-layers than older queens that results in more honey. Queen raising also saves the beekeepers money. Purchasing queens from a queen breeder is expensive and sometimes queen should not adapt well in new climate.

The present study was therefore planned to understand the effect of nutritional supplements i.e. vitamins and proteins on queen rearing, determine the conditions and time of the year best suited for queen rearing and make useful information available to the beekeepers.

\section{MATERIALS AND METHODS}

Study area: This study was carried out at the apiary of Apis mellifera, maintained by the Department of Zoology, Panjab University, Chandigarh at farmer's field in 
village Togan, Chandigarh $\left(\mathrm{P}_{1}\right)$ and a private apiary of A. mellifera maintained by beekeeper in the village Parol, Punjab $\left(\mathrm{P}_{2}\right)$.

Experimental design: Honey bee colonies undergo natural swarming during autumn and spring season. Studies were conducted during these seasons which are ideal for queen rearing in this part of the country.

Preparation of experimental colonies: Four colonies named as $\mathrm{C}_{1}, \mathrm{C}_{2}, \mathrm{C}_{3}$ and $\mathrm{C}_{4}$ were selected for the experiment at each location. Each of these was a divide prepared by removing the super from a strong colony. The already present queen was given to the super while the brood chambers were rendered queen less. In this way, four (i.e.10-frame) queen less colonies were obtained. These were brought to equivalent status in terms of strength, brood and stores before commencing the experiment.

Preparations of nutritional supplement solutions: The nutrient supplement solutions named as $\mathrm{S}_{1}, \mathrm{~S}_{2}, \mathrm{~S}_{3}$ and $\mathrm{S}_{4}$ were prepared by following a protocol of Herbert et al., (1985) with little modifications.:

$\mathrm{S}_{1}$ : Capsules of Becosule were purchased from market and sugar coating was removed to obtain the inside contents. $200 \mathrm{mg}$ of this was dissolved in sugar solution $(1: 1 \mathrm{w} / \mathrm{v})$ till the volume was $500 \mathrm{ml}$.

$\mathrm{S}_{2}$ : 200mg of Thiamine added in sugar solution $(1: 1 \mathrm{w} / \mathrm{v})$ and made the total volume of the solution to $500 \mathrm{ml}$.

$\mathrm{S}_{3}$ : Crushed the yeast tablets to make powder and $10 \mathrm{~g}$ of this were dissolved in sugar solution $(1: 1 \mathrm{w} / \mathrm{v})$. Made total volume to $500 \mathrm{ml}$.

$\mathrm{S}_{4}$ : Sugar solution served as a control prepared by mixing sugar and water ( $1 \mathrm{~kg}$ sugar: 1liter water $\mathrm{w} / \mathrm{v})$ in equal proportions. The plastic beakers containing above four nutritional supplement solutions were kept on the top bar of the frames in each colony and enclosed by an empty super. Bees consumed the entire feed and empty mugs were removed the next day. Colonies were opened and observed for number of healthy queen cells produced one week after feeding the colonies.

\section{RESULTS}

Autumn season: Maize, eucalyptus and arhar were the main crops blooming during autumn season which extends from September to November.

Maximum number of queen cells was recorded in $\mathrm{C}_{3}$ colony at both locations. This colony was fed with protein supplement containing yeast extract. Mortality was observed in $\mathrm{C}_{1}$ colony fed with Becosule (Fig. 1).
No dead bees were observed in other two experimental solutions.

Spring: Brassica followed by khair bloomed in the spring season. Highest number of healthy queen cells was observed again in $C_{3}$ colony (Fig. 2) followed by $\mathrm{C}_{2}$ colonies. Again mortality was observed in $\mathrm{C}_{1}$ colony. Mortality confirmed that there were some components present in $\mathrm{S}_{1}$ solution which were harmful or toxic to bees. This study revealed that higher queen cell production could be obtained in spring season as compared to the autumn season and supplementing with yeast improved the results.

\section{DISCUSSION}

Queen transmits the acquired characters and her own characters i.e. temper, longevity, disease resistance, industriousness, hoarding and swarming tendencies to the colony. To obtain maximum advantage from the beekeeping enterprise, beekeepers must have good queen. A young queen is more prolific and vigorous as compared to old one. Queen therefore needs to be replaced from time to time. The idea of production of queens from naturally builds cells was given by Wagner, Langstroth and I.A Root (Eckert and Shaw, 1960). The methods of queen cell construction and rearing of queens were improved and modified by Johanson and Johanson (1973); Laidlaw (1979) and Wongsiri et al. (1990). Queens can be reared either by using natural queen cells (Miller, 1912) or by artificial queen cups and grafting larvae in them (Doolittle, 1915; Laidlaw, 1979; Wongsiri et al. 1990; Kumar and Kumar, 1999; Kumar and Kumar, 2000). In commercial queen rearing method (Laidlaw, 1979; Ruttner, 1983) larvae of right age (12-24hrs) are grafted into artificially prepared wax or plastic cups. These are raised in queen cells by the worker bees and fed the queen brood food, thus determining the fate of the totipotent larvae and changing them into queens. Wongsiri et al. (1990) observed that queen cell production could be stimulated by sugar feeding. Chang and Hsieh (1993) used natural tea pollen and soybean mixture in sugar syrup and reported that supplementing diet with natural pollen gave the best results. Eckert and Shaw (1960) observed that strong colonies, presence of larvae of appropriate age (i.e. 24 hrs. or younger), abundance of nurse bees, availability of food were prerequisites to the production of good queen. Winston (1987) reported that increased

Table 1. Queen cell production in experimental colonies fed with different nutritional supplements at Department apiary and Private apiary during autumn season.

\begin{tabular}{cccccccc}
\hline \multicolumn{3}{c}{$\mathbf{P}_{\mathbf{1}}$ (Department apiary) } & & \multicolumn{3}{c}{$\mathbf{P}_{\mathbf{2}}$ (Private apiary) } \\
\cline { 2 - 3 } \cline { 5 - 6 } Colony No. & Solutions & No. of cells & & Colony No. & Solutions & No. of cells \\
\hline $\mathrm{C}_{1}$ & $\mathrm{~S}_{1}$ & 1 & & $\mathrm{C}_{1}$ & $\mathrm{~S}_{1}$ & 2 \\
$\mathrm{C}_{2}$ & $\mathrm{~S}_{2}$ & 2 & & $\mathrm{C}_{2}$ & $\mathrm{~S}_{2}$ & 3 \\
$\mathrm{C}_{3}$ & $\mathrm{~S}_{3}$ & 3 & & $\mathrm{C}_{3}$ & $\mathrm{~S}_{3}$ & 4 \\
$\mathrm{C}_{4}$ & $\mathrm{~S}_{4}$ & 1 & & $\mathrm{C}_{4}$ & $\mathrm{~S}_{4}$ & 1 \\
\hline
\end{tabular}


Table 2. Queen cell production in experimental colonies fed with different nutritional supplements at Department apiary and Private apiary during spring season.

\begin{tabular}{cccccccc}
\hline \multicolumn{3}{c}{$\mathbf{P}_{\mathbf{1}}$ (Department apiary) } & & \multicolumn{3}{c}{$\mathbf{P}_{\mathbf{2}}$ (Private apiary) } \\
\cline { 2 - 3 } \cline { 5 - 7 } Colony No. & Solutions & No. of cells & & Colony No. & Solutions & No. of cells \\
\hline $\mathrm{C}_{1}$ & $\mathrm{~S}_{1}$ & 1 & & $\mathrm{C}_{1}$ & $\mathrm{~S}_{1}$ & 2 \\
$\mathrm{C}_{2}$ & $\mathrm{~S}_{2}$ & 3 & & $\mathrm{C}_{2}$ & $\mathrm{~S}_{2}$ & 4 \\
$\mathrm{C}_{3}$ & $\mathrm{~S}_{3}$ & 5 & & $\mathrm{C}_{3}$ & $\mathrm{~S}_{3}$ & 7 \\
$\mathrm{C}_{4}$ & $\mathrm{~S}_{4}$ & 2 & & $\mathrm{C}_{4}$ & $\mathrm{~S}_{4}$ & 2 \\
\hline
\end{tabular}

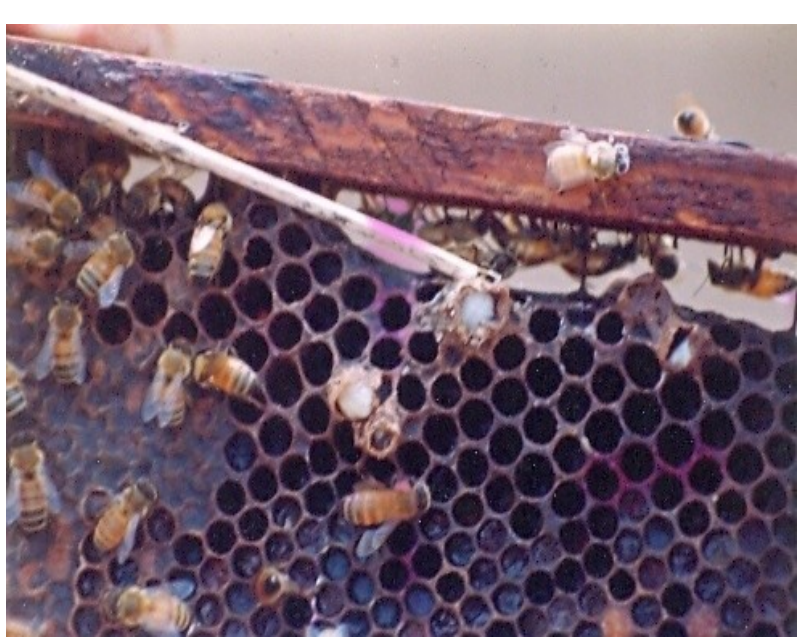

Fig. 1. Queen cells raised by worker honey bees in the experimental colonies fed on becosule (B-complex forte with vitamin $C$ ) in sugar solution at private apiary during autumn. Mortality also seen.

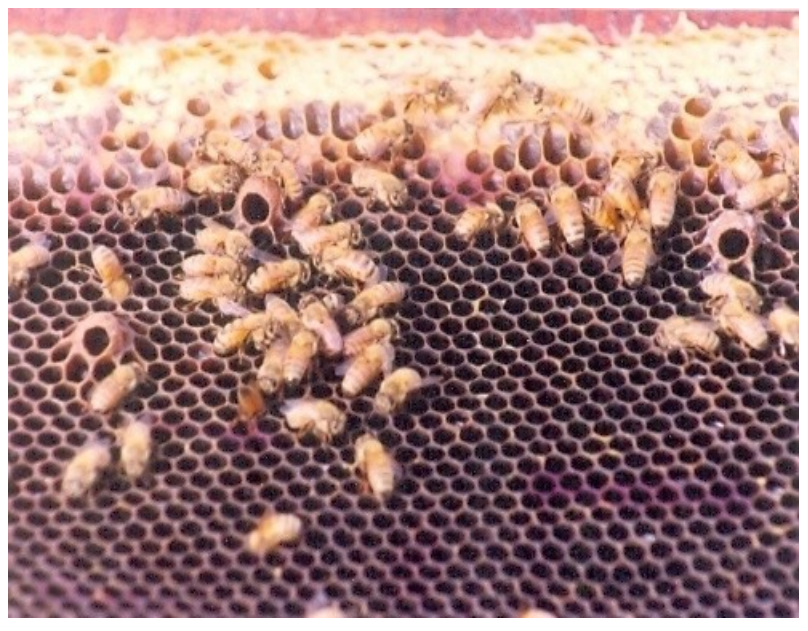

Fig. 2. Queen cells raised by worker honey bees in the experimental colonies fed yeast (protein supplement) in sugar solution at Department apiary during spring.

availability of protein food enhanced the development of hypophyrngeal glands that are associated with production of brood food. Brodschneider and Crailsheim (2010) studied that brood production and larval development is strongly dependent on the availability of protein. Maurizio (1950) reported that development of hypophyrengeal gland and fat bodies were normal on vitamin free diet. Haydak and Dietz (1965) and Anderson and Dietz (1976) studied the influence of vitamin pyridoxine and inositol on larval development and reported that these were required for normal development. During present studies the influence of vitamin $\mathrm{B}_{1}$ (thiamine), when tested revealed that this vitamin could increase queen cell production. Becosule i.e. vitamin B-complex in combination with vitamin C however, did not give very good results, some mortality was observed with this supplement and the number of queen cells produced was not better than the control. Herbert et al. (1985) reported that vitamin C fed to adult workers resulted in a higher brood survival rate than vitamin $\mathrm{C}$ deprived diet. In the present case it is probable that in it some component of vitamin B was toxic. However negative influence of Vitamin $\mathrm{C}$ can be ruled out in the light of the finding of Herbert et al. (1985). Kaftanoglu et al., (2010) studied that sugar composition in the diet also affect positively as it increase ovarioles numbers, average larval survival and their weights.

\section{Conclusion}

The present study concluded that commercial queen cell production was better in the season of spring and was positively influenced by the nutrient yeast supplement. The order of queen cell production was as Yeast $>$ Thiamine $>$ Becosule. The use of becosule is not recommended because some of the components of this nutrient are toxic which leads to mortality of bees.

\section{ACKNOWLEDGMENT}

The authors would like to thank for the research facilities provided by the Department of Zoology, Punjab University, Chandigarh, for assistance at various stages of this research work.

\section{REFERENCES}

Anderson, L.M. and Dietz, A. (1976). Pyridoxine requirement of the honeybee (Apis mellifera) for brood rearing. Apidologie, 7: 67-84.

Brodschneider, R. and Crailsheim, K. (2010). Nutrition and health in honey bees. Apidologie, :1-17.

Chang, C.P. and Hsieh, F.K. (1993). Factors affecting royal jelly production. In: Asian Apiculture (L.J. Connor, T.E. Rinderer, H.A. Sylvester and S. Wongsiri eds.) Wicwas Press U.S.A. pp. 316-326.

Doolittle, G.M. (1915). Scientific queen-rearing as practically applied; being a method by which the best of queen -bees are reared in perfect accord with nature's ways. American Bee Journal; $6^{\text {th }}$ edition, Published by 
Hamilton, III USA. 126 pp.

Eckert, J.E. and Shaw, F.R. (1960). Beekeeping. The Macmillan Company, New York. pp 536.

Haydak, M.H. and Dietz, A. (1965). Influence of the diet on the development and brood rearing of honeybees. In:Proc. Int. beekeeping Congr., Bucharest, 20:158-162.

Herbert, E.W., Jr, Vanderslice, J.T. and Higgs, D.J. (1985). Vitamin $\mathrm{C}$ enhancement of brood rearing by caged honeybees fed a chemically defined diet. Archives of Insect Biochemistry and Physiology, 2: 29-37.

Johanson, T.S.K. and Johanson, M.P. (1973). Methods for rearing queens. Bee Wild., 54: 149-175.

Kaftanoglula, Linksvayer, T.A. and Page, Jr, R.E. (2010). Rearing honey bees, Apis mellifera, in vitro 1: Effects of sugar concentrations on survival and development. Journal of Insect Science, 11: 1-10.

Kalia, P., Kumar, N.R. and Harjai, K. (2013). Phytochemical screening and antibacterial activity of different extracts of propolis. International journal of pharmaceutical and biological research. 3(6): 219-222.

Kaur, R., Kumar, N.R. and Harjai, K. (2013a). Phytochemical analysis of different extracts of bee pollen. International Journal of Pharmaceutical and Biological Research, 4 (3): 65-68

Kaur, R., Kalia, P., Kumar, N.R. and Harjai, K. (2013b). Phytochemical analysis of different extracts of bee pollen. Journal of Applied and Natural Science, 5 (2): 420-422.

Kaur, R. and Kumar, N.R. (2013c). Pollen foraging activity of Apis mellifera during autumn season in Chandigarh. Halteres, 4: 12-14.
Kumar, R. and Kumar, N.R. (2000) Queen rearing and royal jelly production in Asian honey bee Apis cerana. In: Asian bees and beekeeping (M Matsuka, S. Wongsiri and K.K. Shrestha eds.) Oxford and IBH Publishing House, pp. 145-147.

Laidlaw, H.H. Jr (1979). Contemporary queen rearing. Dadant and sons pub. Hamilton,II.

Kumar, N.R. and Kumar, R. (1999). Artificial queen rearing in Asian honey bee Apis cerana Fabr. In: Insects and environment. (H.R. Pajni, P.K.T wari, Deepinderjit eds.). Society of environmental scientists, Pub. pp. 86-88.

Maurizio, A. (1950). The influence of pollen feeding and brood rearing on the length of life and physiological condition of the honeybee. Bee Wild, 31: 9-12.

Meda, A., Lamien, E.C., Millogo, J., Romito, M., Nacoulma, O.G. (2004). Ethanopharmacological communication therapeutic uses of honey and honeybee larvae in central Burkina Faso. Journal of Ethnopharmacoly, 95(1): 103-7.

Miller, C.C. (1912). How best queens can be secured. American Bee Journal, 52: 243.

Ruttner, F. (1983). Queen rearing: Biological basis and technical instruction. Bucharest: Apimondia Publishing House, pp. 358.

Schmickl, T. and Crailsheim, K. (2004.) Inner nest homeostasis in a changing environment with special emphasis on honey bee brood nursing and pollensupply. Apidologie, 35: 249-263.

Winston, M.L. (1987). The biology of the honeybee. Haward Uni. Press. England, pp. 281.

Wongsiri, S., Lai, Y., and Sylvester, H.A. (1990). Queen rearing with Apis cerana. American Bee Journal, 130: 32-35. 